UDC 371.315 .5

DOI: 10.52534/msu-pp.7(3).2021.9-17

\author{
Varvara P. Chernenko*, Olena S. Hrytsiuk, Natalia H. Kyrylakha, Tetiana S. Bryl \\ Kremenchuk Mykhailo Ostrohradskyi National University \\ 39600, 20 Pershotravneva Str., Kremenchuk, Ukraine
}

\title{
Development of Logical Thinking in Creative Computer Science Lessons Using Inventive Problem-Solving Technology
}

\begin{abstract}
Article's History:
Received: 25.04.2021

Revised: 05.07.2021

Accepted: 31.08 .2021

\section{Suggested Citation:}

Chernenko, V.P., Hrytsiuk, O.S., Kyrylakha, N.H., \& Bryl, T.S. (2021). Development of logical thinking in creative computer science lessons using inventive problem-solving technology. Scientific Bulletin of Mukachevo State University. Series "Pedagogy and Psychology", 7(3), 9-17.
\end{abstract}

\begin{abstract}
Modern school education should provide the best conditions for realising students' potential and reveal all the natural inclinations inherent in them. The use of technology for solving inventive problems in creative Computer Science lessons organises thinking and promotes students' critical thinking development. Therefore, the child develops logical thinking, increases motivation to learn, and independence. This study aims to develop methodological aspects of using inventive problem-solving technology to develop students' logical thinking in creative Computer Science lessons. The following approaches were used in the study: theoretical analysis and generalisation of scientific data on the subject matter; observation, questionnaires, testing, pedagogical experiment and methods of statistical processing of findings. In the process of research, the features of the formation of logical thinking of students in Computer Science lessons in primary school were analysed, the expediency of using techniques of technology for solving inventive problems as a means of developing logical thinking of primary school students in creative Computer Science lessons was substantiated. A system of tasks for the development of logical thinking in $8^{\text {th }}$-grade students was developed and implemented in the educational process, which allowed experimentally testing the pedagogical effectiveness of the level of formation of logical thinking and its development in $8^{\text {th }}$-grade students. The study of the level of formedness of logical thinking in $8^{\text {th }}$-grade students in such components as the level of development of the ability to analyse the conditions of the problem (the "logical problems" method) and the level of development of logical thinking (the "logical and quantitative relations" method) is carried out. The results of the pedagogical experiment confirmed the hypothesis that the development of logical thinking of $8^{\text {th }}$-grade students during creative Computer Science lessons is influenced by the technology of solving inventive problems
\end{abstract}

Keywords: creative pedagogy, creative task, primary school, "Bebras" competition

\section{INTRODUCTION}

The changes taking place in Ukraine and the rapid dynamic development of humanity determine the need for an individual to develop the ability to solve complex intellectual problems. According to R. Milyan, "today, developed logical thinking is considered not only as the most important condition for a student's academic performance, but also as the basis for the development of his motivated activity, the ability to solve problems that arise in real life, and the ability to evaluate their activities" [1, p. 124]. In particular, the author assigns particular importance to the influence of logical thinking on the value formation of the individual, which, for its part, implies stability, imitation of certain behaviour and regulation of personality motivation [1, p. 124]. One way or another, the development of logical thinking in students is becoming an increasingly urgent problem for modern society. Computer Science, as a fundamental science, understand the role of Information processes in nature, society, and technology, is a powerful tool for developing logical thinking through the use of ICT. For example, the Computer Science curriculum for general education institutions, in particular grades 5-9, "is based on a developmental and competence approach that provides for the 
formation of key competencies, in particular one of the main competencies in natural sciences and technology the ability to apply logical, algorithmic, structural and system thinking to solve problem situations in life" [2]. Ultimately, due to the developing component, the Computer Science curriculum contributes to the development of all types of thinking, the improvement of creative inclinations, the development of ethical and aesthetic values, and the ability to establish causal relationships between environmental processes and phenomena [2, p. 5].

Notably, many scientists have dealt with the problems of developing the logical thinking of students, in particular high school students. Thus, T.A. Vakalyuk [3], I.V. Lovyanova [4], O.O. Girya [5], A.M. Silveistr, M.O. Moklyuk [6] in their studies covered the methodological features of the development of logical thinking of high school students and primary school students in the process of teaching subjects of the natural and mathematical cycle. For their part, the study of the peculiarities of logical thinking of primary school students was carried out by such authors as I.I. Ostapyovska [7], O.S. Moyko [8], Yu.O. Muzyka [9], O.M. Yashchuk [10] et al., who considered the problems of the relationship between logical thinking and mental development of students, focusing on the issue of teaching younger students to solve logical problems. However, the problem of developing logical thinking of primary school students in Computer Science lessons was rather neglected by both Ukrainian and foreign researchers. Many foreign authors studied the impact on the development of logical thinking by solving problems of the International Computer Science Competition "Bebras" [11; 12]. For Example, G. Delal and D. Oner investigated the acquisition of logical thinking skills of students of the $6^{\text {th }}$ grade of Istanbul schools in Computer Science classes who solved problems from the Bebras competition without using a computer [11]. The authors claim that this method of developing logical thinking provides an opportunity for students with a negative attitude to computer education to make the process of developing logical thinking more enjoyable. Considering a computerised approach to the development of logical thinking of primary school students, A. Yushkeviciene empathises that STEAM education can be considered as an educational technology that improves the skills of logical and creative thinking [13]. However, in this case, it is important to support Computer Science teachers by providing appropriate content, forms, methods, tools for teaching and assessing students' logical thinking to achieve a positive result. Russian researchers (G.S. Altshuller [14], A.A. Gin [15], M.M. Zinovkina, V. V. Utemov [16] et al.) argue that the development of logical thinking of schoolchildren is promoted by the Theory of Inventive Problem Solving (TIPS), developed by G.S. Altshuller, which is "one of the innovative educational technologies that can increase the effectiveness of education in general and develop logical thinking of students" [14]. Ultimately, this educational technology forces applicants to develop systems thinking, create an innovative product and find new methods of solving problems [14]. Thus, using the techniques and methods of TIPS technology, it is possible to form a single scientific and systematic picture of the world among students, at the same time, significantly increasing the effectiveness of learning.

The purpose of the study is the development of methodological aspects of using the techniques and methods of TIPS technology as a means of developing logical thinking of primary school students in creative Computer Science lessons.

\section{MATERIALS AND METHODS}

Theoretical methods, namely theoretical analysis and generalisation of scientific data, allow identifying the features of the development of logical thinking of primary school students in Computer Science lessons and substantiate the expediency of using TIPS technology as a means of developing logical thinking of schoolchildren in Computer Science lessons.

To test the hypothesis of whether TIPS-learning technology affects the development of logical thinking of $8^{\text {th }}$-grade students during Computer Science classes, an experimental study was conducted in which $548^{\text {th }}$-grade students studying in institutions of general secondary education in Kremenchuk, Poltavska Oblast. Experimental work was a component of teaching Computer Science to $8^{\text {th }}$-grade students, during which the introduction of TIPS technology was carried out in the first subgroups of classes (experimental group - 28 students), and conventional pedagogical technologies were used in the second subgroups (control group - 26 students). The experiment consisted of three stages: ascertaining, formative, and summative, continued during the first semester of children's education in schools. At the first stage, the experimental hypothesis was tested: whether there are statistically significant differences in the levels of development of the ability to analyse the conditions of the problem and the development of logical thinking between the experimental and control groups at the beginning of the experiment. Students of both groups were involved in the ascertaining experiment. Further, the experimental hypothesis of the formative stage was tested: whether TIPS - the technology of teaching Computer Science - affects the development of logical thinking of students of the primary school. Only an experimental group of 28 students was involved in the formative experiment. At the summative stage, two experimental hypotheses were tested: whether there are statistically significant differences in the levels of development of the ability to analyse the conditions of the problem and the development of logical thinking between the experimental and control groups at the end of the experiment, and whether statistically significant differences between the control and experimental groups will be identified in the results of the International Computer Science Competition "Bebras" for grades 8-9 for 2019 [17]. All students were involved in the summative experiment.

All statistical hypotheses were tested at all stages of the experiment using the Pearson criterion. The advantage 
of the criterion is that it allows comparing features that are presented on any scale, starting from the nominal scale. All calculations based on the Pearson statistical criterion were performed using SPSS 21 statistical data analysis package. The study of the level of formedness of logical thinking, conducted on such components as the ability to analyse the conditions of the problem and the level of development of logical thinking, was conducted twice: in September 2019 and in December 2019 using two methods:

- methods "Logical tasks", the purpose of which is to identify students' level of formedness of theoretical analysis and internal action plan, namely: the level of development of the ability to understand the educational task, the level of development of the ability to plan their actions and the level of development of the ability to analyse the conditions of the task in students. In this study, it was the third indicator that was of interest. According to this method, students had to solve 22 logical problems. To determine the level of development of the ability to analyse problem conditions, the number of solved problems from 5 to 16 was checked [18].

- methods of "Logical and quantitative relations", the purpose of which is to assess the level of formedness of logical thinking of students by solving 20 problems to clarify logical and quantitative relations in 10 minutes. This technique allows quickly assessing the level of development of logical thinking of students, taking into account two aspects of the internal plan of mental actions: logic of thinking and counting in head with memorising intermediate results. Depending on the number of correctly solved problems, it can be stated what level of development of logical thinking in a child is: from very low to very high [19].

\section{RESULTS AND DISCUSSION}

It is worth starting with the fact that it is possible to develop logical thinking of students by means of each of the sections of Computer Science, however, to do this, the teacher must teach students to analyse the task, learn to independently find and correct mistakes. The teacher should systematically use tasks in each lesson that would contribute to the development of students' cognitive interest and independence. Ultimately, the goal of studying Computer Science in a modern school is to create a system of creative tasks focused on both the formation of computer literacy and establishment of logical thinking of the individual. Thus, A.A. Gin understands a creative task as "one where either everything as a whole is new (not familiar to the subject), or, to a lesser extent, contains significant novelty, which causes significant mental effort, a special search, finding a new way to solve it" [20]. Such tasks require students to be observant, creative, and original. The effective development of logical thinking of students, as a prerequisite for the development of algorithmic thinking in them, is promoted by interesting tasks "for reasoning", puzzles, non-standard practical tasks, problem-creative tasks, group projects, discussions [21]. However, it is the use of TIPS in Computer Science lessons that forms students' flexible and non-trivial thinking, devoid of stereotypes, and helps to increase students' cognitive activity and motivation to learn. The purpose of TIPS pedagogy is to prepare students for solving non-standard problems. It involves the use of a large number of specialised exercises, but, first of all, forms the habit of solving innovative problems, the ability to distinguish a problem solved in standard ways from a creative problem [20].

When teaching Computer Science using TIPS technology, students retain a positive motivation for success and a desire to move on to the next stage of work. The main elements of logical thinking that are developed by the methods and techniques of TIPS technology in Computer Science lessons are: situation analysis (establishing causeand-effect relationships, identifying hidden dependencies and relationships, the ability to substantiate and reason, the ability to predict consequences); solving problem situations (system analysis, system of logical exercises, brainstorming, synectics); the ability to integrate and synthesise information (the ability to draw conclusions, the ability to organise information) [22]. Finally, an empirical study was conducted to confirm the impact of TIPS technology on the development of students' logical thinking during Computer Science classes. The study considers the results of a pedagogical experiment to develop logical thinking in $8^{\text {th }}$-grade students in creative Computer Science lessons using TIPS technology. First of all, to ensure that the level of retained knowledge is statistically the same in the control and experimental groups, the first lesson was tested to identify the retained knowledge of Computer Science students for the $7^{\text {th }}$-grade. Figure 1 shows a histogram of the distribution of students' retained knowledge levels for the $7^{\text {th }}$-grade. Based on the Pearson criterion, it turned out that there were no statistically significant differences in the levels of residual knowledge of students in the groups (significance level $R \geq 0.05$ ), that is, students who fell into different subgroups had approximately the same level of knowledge in Computer Science for the $7^{\text {th }}$-grade.

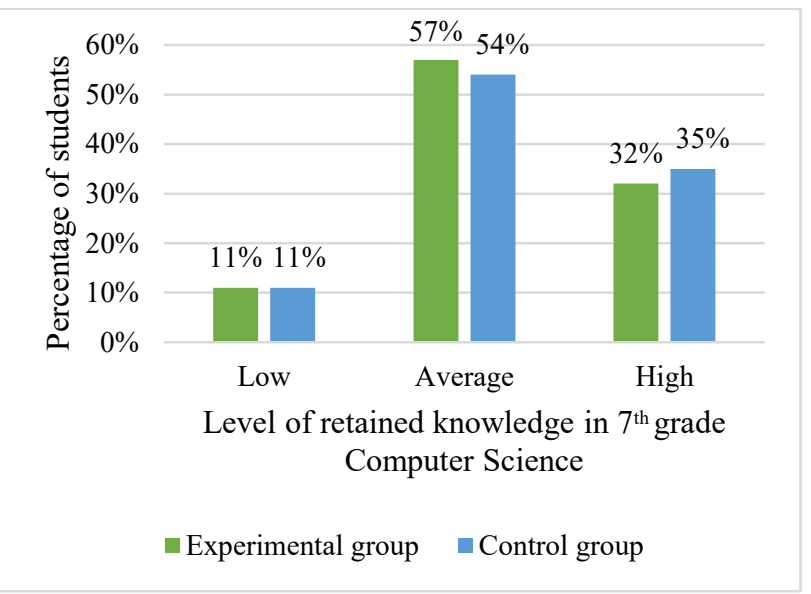

Figure 1. Histogram of the distribution of levels of retained knowledge in Computer Science of the $7^{\text {th }}$-grade students

Source: compiled by the authors 
The second stage of the study involved the development of logical thinking using TIPS technology during creative computer science lessons in the $8^{\text {th }}$-grade in an experimental group. Structure of the creative lesson by M. Zinovkina [16] contains 8 blocks: motivation, educational content, psychological relief, puzzle, intellectual warm-up, educational content, computer game, summary. Each stage of the lesson involves the use of TIPS techniques methods that stimulate students' logical thinking. Table 1 shows the general structure of a creative Computer Science lesson.

Table 1. General structure of a creative Computer Science lesson

\begin{tabular}{c|c} 
Block number and characteristics & Time (min.) \\
Block 1. Motivation. Video watching & 5 \\
\hline Block 2. Theoretical block 1. Presentation & 3 \\
\hline Block 3. Psychological relief & 5 \\
\hline Block 4. Puzzle. Collective work & 10 \\
\hline Block 5. Theoretical block 2. Mind map & 7 \\
\hline Block 6. Intellectual warm-up. Work in groups & 5 \\
\hline Block 7. Computer game & 3 \\
\hline Block 8. Summary. Homework assignment & \multicolumn{2}{|c}{} \\
\hline
\end{tabular}

Source: compiled by the authors based on studies by M.M. Zinovkina [16]

For example, consider each block of a creative Computer Science lesson for the 8th grade on the topic "Coding". The developmental component of such a lesson is to improve logical thinking based on observations, comparisons, awareness of the obtained material using elements of TIPS technology; continue to develop skills in working with information technologies [23].

Block 1. Motivation. As a warm-up at the beginning of the lesson, the technique of solving non-standard problems is used to motivate learning activities. For example, a riddle is solved to find out the topic of the lesson. Then students can be offered to watch the video "Top-10 unsolved ciphers" [24].

Block 2. Theoretical block 1. Presentation on the topic "Historical excursion". In this part of the lesson, the teacher demonstrates a presentation on the topic of the lesson.

Block 3. Psychological relief. The purpose of this part of the lesson is to encourage students and help them move on to the next stage of the lesson. The students can be asked to do the following exercises: 1 ) turn over the neck so that the neck itself does not move (turn the entire body); 2) clap hands with one hand (clap together with a neighbour).
3) pat yourself on the head without touching your hand (using some object or a neighbour's hand).

Block 4. Puzzle. Collective work. This block is a system of puzzles embodied in real objects, in the design of which the original idea is implemented. Students are invited to solve logical problem No. 11 from the International Computer Science Competition "Bebras" for grades 8-9 in 2018 [17].

Block 5. Theoretical block 2. Mind map. The use of visualisation of information in the form of mind maps in the learning process, as confirmed by practice and expert assessments of studies in the field of pedagogy, is a very effective form of activation and development of system thinking. The method of intelligence cards contributes to the comprehensive intellectual development of both teacher's and students' personalities, ensuring consistency and integrity of knowledge. In addition, the use of mind maps contributes to the development of attention, logical thinking, memory, and helps to establish and use associative connections. The second theoretical block is proposed to be presented in the form of a mind map created using the XMind environment (Fig. 2).

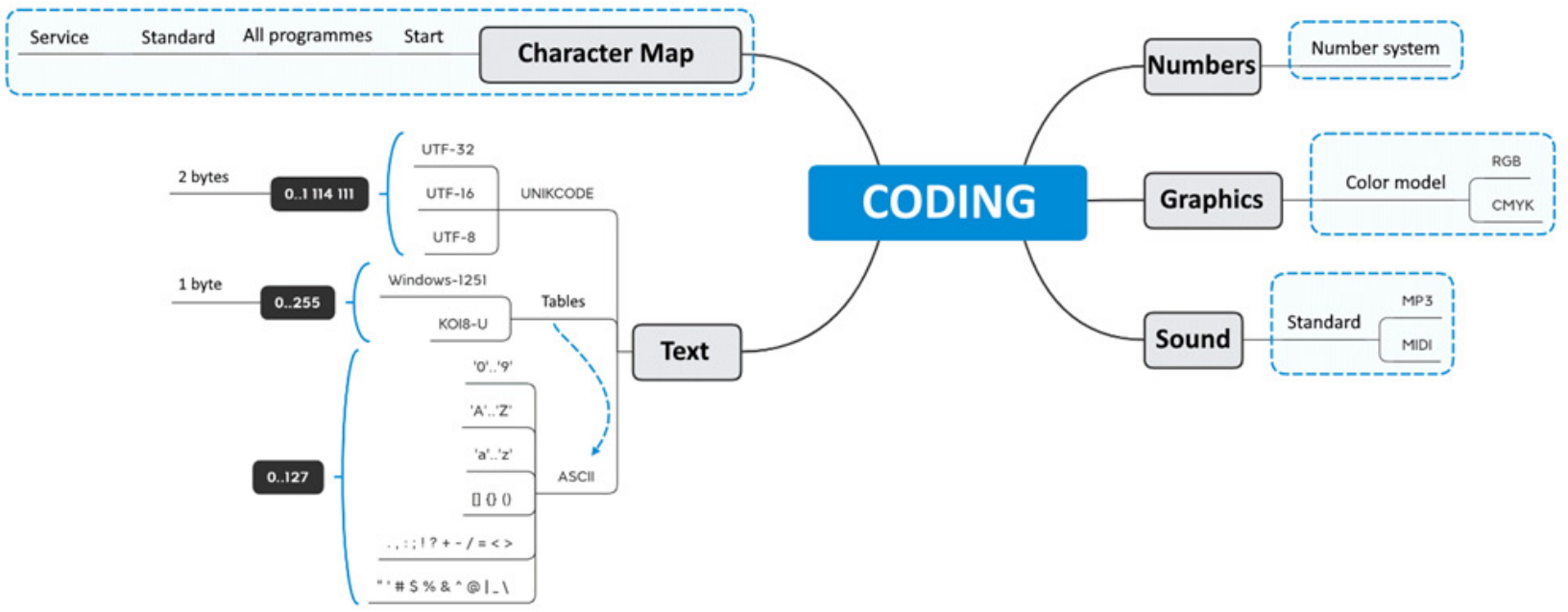

Source: compiled by the authors

Figure 2. Mind map on the topic of the lesson 
Block 6. Intellectual warm-up. Work in groups. This block is a system of tasks aimed at developing motivation, logical thinking, and creative abilities of students. As an example, students are grouped into two groups, each group is given a task in the form of a table (Table 2). Using the word-making method, students need to determine the encoded word as quickly as possible, and then use the Caesar cipher to decode it (condition: shift to the left by 4 characters, answer: шифр).

Table 2. Task conditions for the first group

\begin{tabular}{|c|c|c|c|c|}
\hline & Alphabet & Number system & Decoding & Message \\
\hline $\begin{array}{c}\text { Sequence of signals of different } \\
\text { nature }\end{array}$ & B & M & $\mathrm{P}$ & Я \\
\hline $\begin{array}{l}\text { A set of rules for writing numbers } \\
\text { using a specific set of characters }\end{array}$ & $\mathrm{y}$ & K & Д & Л \\
\hline The reverse coding process & Ч & $\mathrm{C}$ & III & A \\
\hline $\begin{array}{c}\text { A set of valid characters that form } \\
\text { messages }\end{array}$ & $\Phi$ & $\mathrm{O}$ & $\mathrm{H}$ & $\mathrm{T}$ \\
\hline
\end{tabular}

Source: compiled by the authors

Block 7. This block provides motivation and development of logical thinking, provides a system of computer puzzle games adapted to the age of students. According to the specifics of the subject, computer support is provided in almost all blocks, so sometimes this block is not allocated.

Block 8. Summary. Homework assignment. This block provides feedback to students in the lesson and provides a qualitative and emotional assessment of the lesson itself to students.

Finally, after three stages of experimental research, in particular testing the residual knowledge in the experimental and control groups, conducting creative lessons in the experimental group and comparing the level of formedness of logical thinking of $8^{\text {th }}$-grade students of two groups in Computer Science lessons, the following conclusions are drawn:
1. According to the results of the ascertaining (first) stage, there were no statistically significant differences in the levels of formedness of the ability to analyse the conditions of the problem and the development of logical thinking between the experimental and control groups.

2. At the end of the formative stage of the experiment, no students in the experimental group showed a low level of development of the ability to analyse the task conditions; the percentage of students with an average and high level increased from $68 \%$ to $79 \%$ and from $14 \%$ to $21 \%$, respectively (Fig. 3).

In addition, the number of students with a high level of development of logical thinking increased by $11 \%$, and $3 \%$ of students with a very high level of development of logical thinking appeared (Fig. 4).

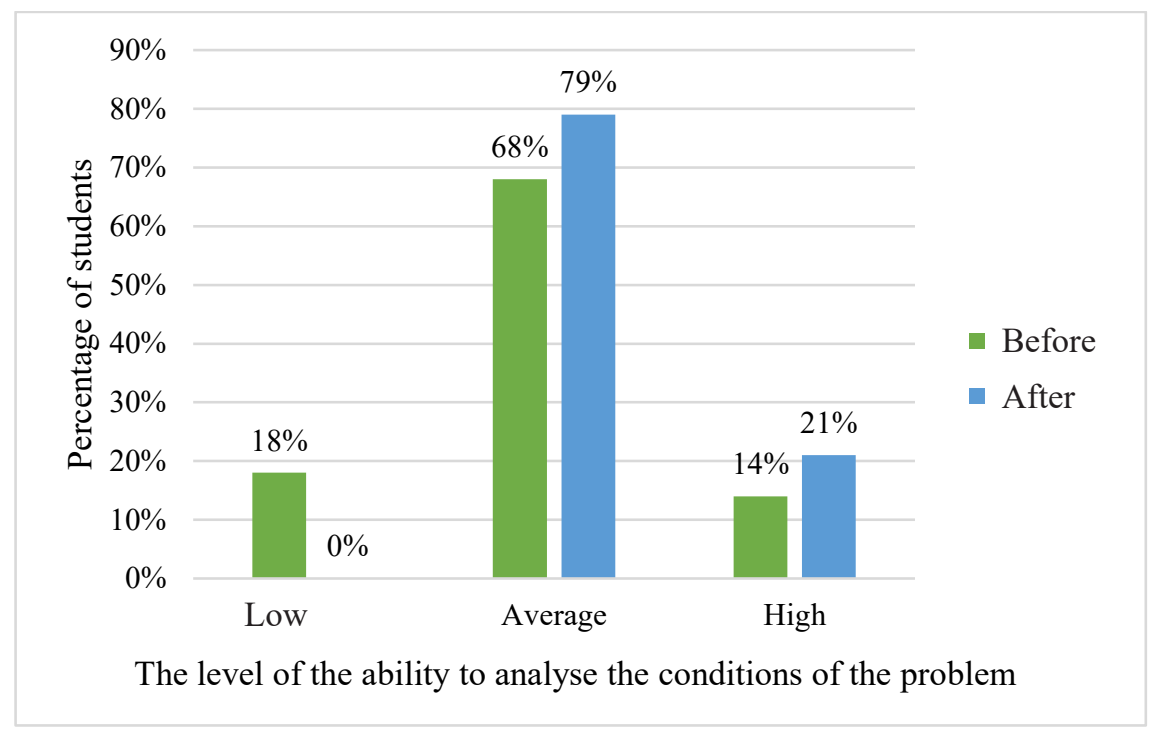

Figure 3. Results of a formative experiment using the "Logical problems" method

Source: compiled by the authors 


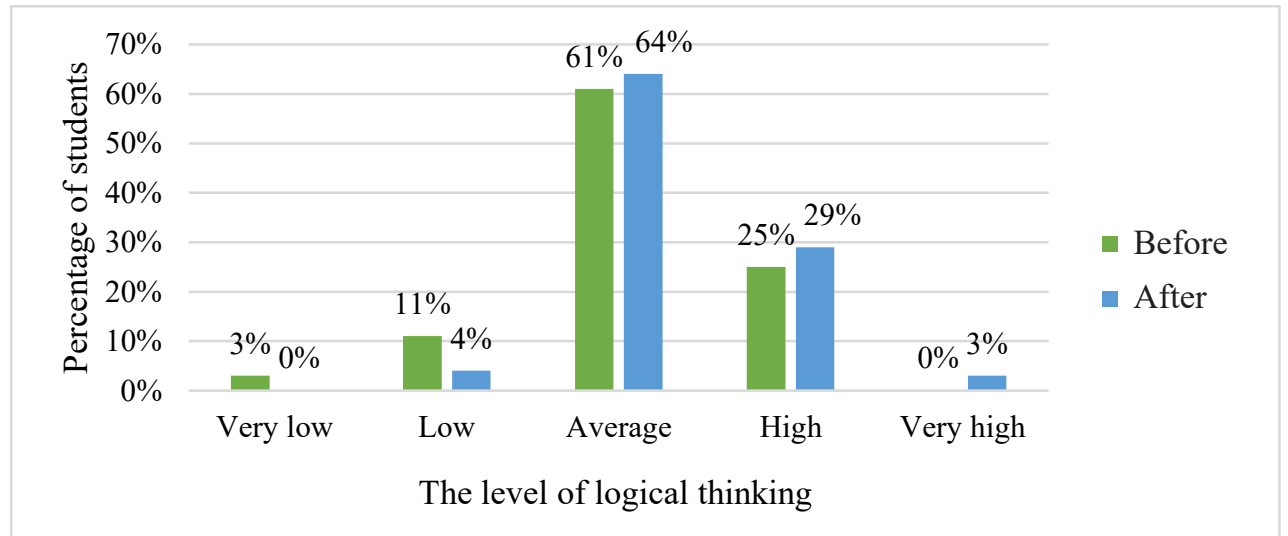

Figure 4. Results of a formative experiment using the "Logical and quantitative relations" method Source: compiled by the authors

3. The results of the summative stage of the experiment indicate the presence of statistically significant differences in the levels of development of the ability to analyse

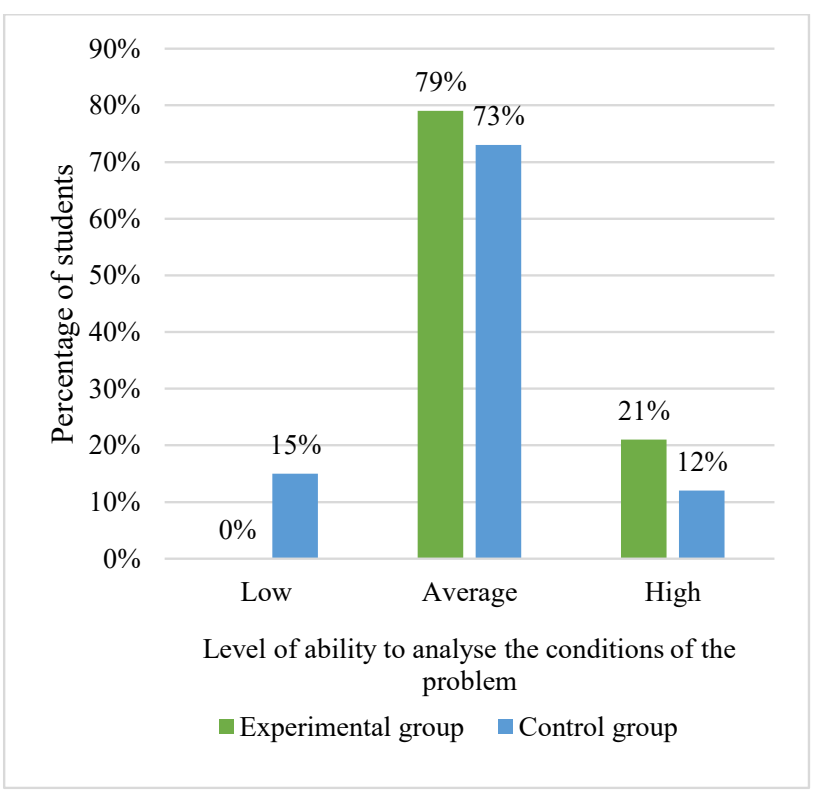

the conditions of the task and the development of logical thinking between the experimental and control groups at the level of significance $\mathrm{R} \leq 0.05$ (Fig. 5a, 5b).

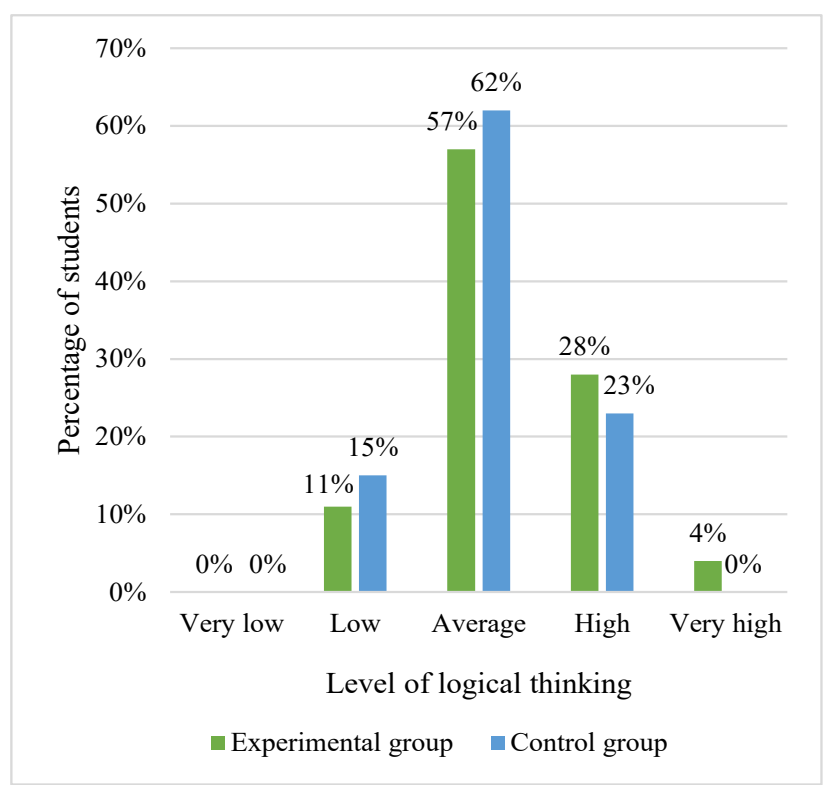

Figure 5. Results of the control experiment:

a) According to the "logical problems" method

Source: compiled by the authors

At the last stage of the experiment, the presence of statistically significant differences between the control and experimental groups was checked based on the results of solving problems of the international competition in Computer Science and computer skills for grades 8-9 for 2019, which contained 18 tasks [17]. The maximum number of points -102 . To interpret the results, the following scale was introduced: 30-62 - low level, 63-84 - average level, 85-102 high level. Figure 6 shows a histogram of the results of the International Computer Science Competition "Bebras". b) According to the "logical and quantitative relations" method

Based on the Pearson criterion, it was found that there were no statistically significant differences in the results of the "Bebras" competition between the experimental and control groups (significance level $\mathrm{p} \geq 0.05$ ). Students of the experimental group solved the competition problems better, but these differences are not statistically significant. According to the authors, this is conditioned by the fact that the tasks of the international "Bebras" competition are quite complex and additional preparation is required to participate in this competition. 


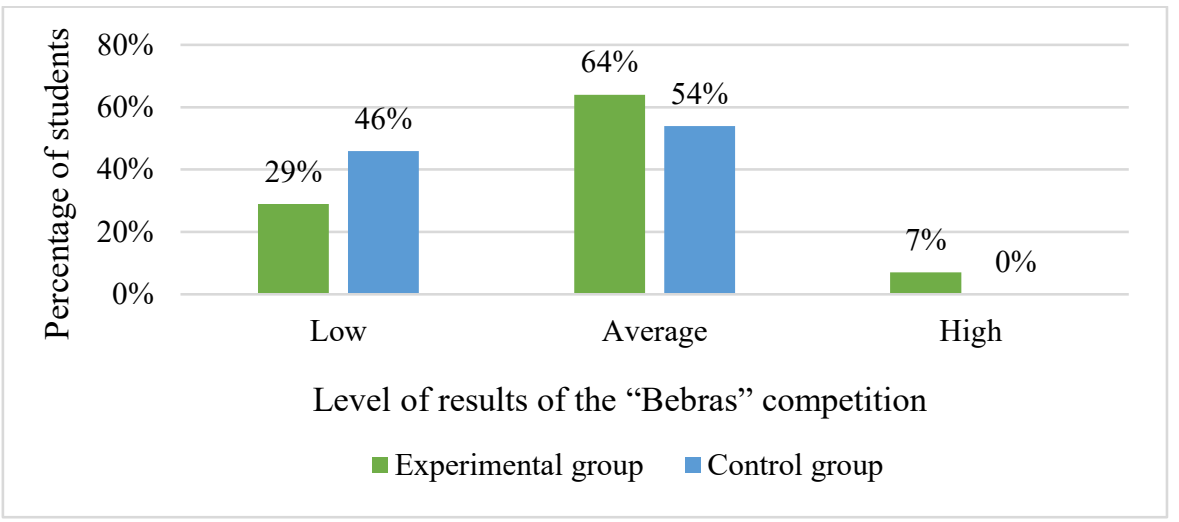

Figure 6. Histogram of distribution of the results of the "Bebras" competition

Source: compiled by the authors

The study results echo a broader question related to the professional development of Computer Science teachers. The ability of Computer Science teachers to develop and implement systems of creative tasks in the learning process also requires them to be able to combine two main components: on the one hand, methods and technologies for teaching Computer Science and developing logical thinking, and on the other hand, a constant reflection of what Computer Science is as a science and its fundamental principles $[24 ; 25]$.

Notably, students' motivation plays an important role in their learning of any subject. A study based on a multi-factor analysis of variance showed that among the nine factors of motivation of secondary and specialised school students to study Computer Science, such as: the value of future work, importance, altruistic motivation, positive school experience, self-efficacy, positive learning experience, social pressure, perceived skills, interest, the factor "value of future work" was the highest, and the factor "interest" was the lowest among motivational factors [26]. This confirms the idea that creative Computer Science lessons using the developed system of creative tasks can increase the "interest" in Computer Science among primary school students.

\section{CONCLUSIONS}

The analysis of scientific and pedagogical literature on the topic showed the development of logical thinking of primary school students in Computer Science lessons contributes to the acquisition of skills to logically evaluate facts, use new experience, combining it with previously acquired ones, to solve non-standard creative problems. At the same time, the use of diagnostic methods for the degree of development of the theoretical method of solving problems in general, the development of operations such as analysis, structuring has shown that the implementation of a system of creative tasks developed by the authors, based on the techniques and methods of TIPS technology at certain stages of the creative Computer Science lesson, increases the level of development of logical thinking in primary school students. The conducted experimental study also shows that the systematic inclusion of creative tasks in the work of a computer science teacher can significantly improve the process of preparing students for participation in the international competition "Bebras". The conducted research proved that only the gradual and purposeful introduction of TIPS technology and methods in creative computer science lessons will affect the development of logical thinking of primary school students.

Thus, in the system of modern school education, TIPS technology is an innovative educational technology, one of the priority tasks of which is the development of logical thinking of primary school students. The conducted research does not claim to be a final solution to the problem of developing the logical thinking of students in the process of teaching computer science. The analysis of its results determines the directions of further research, including the creation of methods for developing students' logical thinking by means of computer-oriented learning.

\section{REFERENCES}

[1] Milian, R.S. (2019). Comparative analysis of definitions "critical thinking" and "logical thinking". Modern Information Technologies and Innovative Teaching Methods in Professional Training: Methodology, Theory, Experience, Problems, 54, 121-125.

[2] The program of informatics for the general secondary education institution. (2017). Retrieved from http://mon.gov.ua/ osvita/zagalna-serednya-osvita/navchalni-programi/navchalni-programi-5-9-klas.

[3] Vakaliuk, T. (2013). Theoretical justification for the necessity of training future teachers of informatics to develop logical thinking of high school students. Pedagogical Sciences: Theory, History, Innovative Technologies, 8(34), 343-352.

[4] Tarasenkova, N., Akulenko, I., Hnezdilova, K., \& Lovyanova, I. (2019). Challenges and prospective directions of enhancing teaching mathematics theorems in school. Universal journal of educational research, 7(12), $2584-2596$. doi: 10.13189/ujer.2019.071205. 
[5] Girya, A. (2013). The development of logical thinking of students in the process of solving chemical tasks. Pedagogical Sciences: Theory, History, Innovative Technologies, 8(34), 360-368.

[6] Silveistr, A., \& Mokliuk, M. (2020). Development of logical thinking in primary school students in physics lessons. Pedagogy of Formation of Creative Personality in Higher and General Education Schools, 73(1), 44-149. doi: 10.32840/1992-5786.2020.73-1.27.

[7] Ostapiovska, I., \& Laskevych, O. (2018). Formation of logical thinking of younger schoolchildren by means of extracurricular work in informatics. Pedagogical Magazine of Volyn, 1(8), 88-93.

[8] Moyko, O. (2019). Development of logical thinking of junior studentsin computer science lessons. Youth and the Market, 11(178), 31-36.

[9] Muzyka, Iu. (2012). Criteria and indicators for measuring the levels of professionalism in the pedagogical activity of a teacher in the formation of logical thinking in younger students. Scientific Bulletin of South Ukrainian National Pedagogical University named after K.D. Ushynskyo, 5-6, 146-153.

[10] Iashchuk, O.M. (2015). Formation of logical thinking of junior schoolchildren in mathematics lessons: Problems and prospects. Psychological and Pedagogical Problems of Rural School, 52, 153-157.

[11] Delal, H., \& Oner, D. (2020). Developing middle school students' computational thinking skills using unplugged computing activities. Informatics in Education, 19(1), 1-13.

[12] Combéfis, S., \& Stupurienè, G. (2020). Bebras based activities for computer science education: Review and perspectives. In K. Kori, \& M. Laanpere (Eds.), Informatics in Schools. Engaging Learners in Computational Thinking (pp. 15-29). Berlin: Springer.

[13] Juškevičienè, A. (2020). STEAM teacher for a day: A case study of teachers' perspectives on computational thinking. Informatics in Education, 19(1), 33-55.

[14] Altshuller, G. (2015). Find an idea. Introduction to TIPS - theory of inventive problem solving. Moscow: Alpina Publisher.

[15] Gin, A.A. (2016). TIPS- pedagogy: Teaching creative thinking. Moscow: Vita-Press.

[16] Utyomov, V.V., \& Zinovkina, M.M. (2013). Structure of a creative lesson of development of the creative person in pedagogical system of NFTM-TRIZ. Koncept, 3, 2841-2845.

[17] Official website of the Bebras International Contest on Informatics and Computer Literacy. (n.d.). Retrieved from http://bober.net.ua/.

[18] Korobko, S., \& Korobko, O. (2006). Psychologist's work with junior schoolchildren. Kyiv: Litera.

[19] Nemov, R.S. (2001). Psychology (Vol. 3). Moscow: VLADOS.

[20] Kert, S.B., Kalelioğlu, F., \& Gülbahar, Ya. (2019). A holistic approach for computer science education in secondary schools. Informatics in Education, 18(1), 131-150.

[21] Chernenko, V., Kozitska, Yu., \& Fedichak, B. (2021). Development of a logical misdirection at creative lessons in informatics for additional TRVZ-technology. In Modern education and science: Problems, perspectives, innovations: Materials of the scientific and practical conference. (pp. 253-256). Kyiv: National Pedagogical Dragomanov University.

[22] Lesson development. (n.d.). Retrieved from http://www.kievoit.ippo.kubg.edu.ua/kievoit/2013/52/52.html.

[23] TOP 10 unsolved codes. (n.d.). Retrieved from https://www.youtube.com/watch?v=GjWVLq8sskU.

[24] Lonati, V. (2020). Getting inspired by Bebras tasks. How Italian teachers elaborate on computing topics. Informatics in Education, 19(4), 669-699.

[25] Bellettini, C., Lonati, V., Malchiodi, D., Monga, M., \& Morpurgo, A. (2018). Informatics and computational thinking: A teacher professional development proposal based on social-constructivism. In S. Pozdniakov, \& V. Dagienè (Eds.), Informatics in School. Fundamentals of Computer Science and Software Engineering (pp. 194-205). Berlin: Springer.

[26] Kori, K., \& Luik, P. (2020). Upper- and lower-secondary students' motivation to study computer science. Informatics in Schools. Engaging learners in computational thinking. In K. Kori, \& M. Laanpere (Eds.), Informatics in Schools. Engaging Learners in Computational Thinking (pp. 69-78). Berlin: Springer. 


\section{Варвара Петрівна Черненко, Олена Сергіївна Грицюк, Наталія Григорівна Кирилаха, Тетяна Сергї̈вна Бриль}

Кременчуцький національний університет імені Михайла Остроградського 39600, вул. Першотравнева, 20, м. Кременчук, Україна

\section{Розвиток логічного мислення на креативних уроках інформатики з використанням технології розв'язування винахідницьких задач}

Анотація. Сучасна шкільна освіта має забезпечити найкращі умови для самореалізації особистості учнів та розкрити всі природні задатки, які в них закладені. Використання технології розв’язування винахідницьких задач на креативних уроках інформатики організовує мислення, сприяє саморозвитку та розвитку критичного мислення учнів, а отже, у дитини розвивається логічне мислення, підвищується мотивація до навчання та самостійність. Метою цього дослідження є розробка методичних аспектів використання технології розв'язування винахідницьких задач як засобу розвитку логічного мислення учнів на креативних уроках інформатики. Для отримання нових результатів у дослідженні були використані такі методи: теоретичний аналіз і узагальнення наукових даних з проблеми дослідження; спостереження, анкетування, тестування, педагогічний експеримент і методи статистичної обробки результатів дослідження. У процесі наукової розвідки проаналізовано особливості формування логічного мислення учнів на уроках інформатики в основній школі, обгрунтовано доцільність використання прийомів технології розв'язування винахідницьких задач як засобу розвитку логічного мислення учнів основної школи на креативних уроках інформатики. Розроблено і впроваджено в освітній процес систему завдань щодо розвитку логічного мислення в учнів восьмого класу, що дала змогу експериментально перевірити педагогічну ефективність рівня сформованості логічного мислення та його розвитку в учнів восьмого класу. Проведено дослідження рівня сформованості логічного мислення в учнів восьмих класів за такими складовими, як рівень розвитку уміння аналізувати умови задачі (методика «Логічні задачі») та рівень розвитку логічного мислення (методика «Логіко-кількісні відносини»). Результати педагогічного експерименту дали змогу підтвердити гіпотезу, що на розвиток логічного мислення учнів восьмого класу під час занять на креативних уроках інформатики впливає технологія розв’язування винахідницьких задач

Ключові слова: креативна педагогіка, творча задача, основна школа, конкурс «Бобер» 